WATER, SOIL AND THE PLANT 
Some other ELBS low-priced editions

Bell and

Woodcock

Chapman and The AlgaE

Chapman

Cobley and

Steele

Cooke

Fogg

Ingold

Kershaw

Marshall and

Williams

Parker and

Haswell

Purseglove

Purseglove

Russell

Street and

Opik

Webster and

Wilson

Wheeler

YIELD

GROWTH Plants
The Diversity of Green Plants Edward

Arnold

Macmillan

Longman

BOTANY OF TROPICAL CROPS

FERTILIZING FOR MAXIMUM

PHOTOSYNTHESIS

BIOLOGY OF FUNGI

QUANTITATIVE AND DYNAMIC

Plant ECOLOGY

Crosby

Lockwood

Staples

Hodder \&

Stoughton

Hutchinson

Educational

Edward

Arnold

Macmillan INVERTEBRATES

A TeXTbOOK OF Zoology: Vol. II Macmillan VERTEBRATES

TROPICAL CROPS DICOTYLEDONS

TROPICAL CROPS MONOCOTYLEDONS

SOIL CONDITIONS AND PLANT

The Physiology of Flowering

AGRICULTURE IN THE TROPICS

Longman

Longman

Longman

Edward

Arnold

Longman

John Wiley, London 


\section{Science in Horticulture Series}

\section{General Editor: Professor L. Broadbent, University of Bath}

This series of texts has been designed for students on courses in horticulture at the Higher National Certificate or Diploma level, but care has been taken to ensure that they are not too specialised for lower-level courses, nor too superficial for university work.

All the contributors to the series have had experience in both the horticultural industry and education. Consequently, the books have a strong practical flavour which should reinforce their value as textbooks and also make them of interest to a wide audience, including growers and farmers, extension officers, research workers, workers in the agrochemical, marketing and allied industries, and the many gardeners who are interested in the science behind their hobby.

The authors are all British, but they have illustrated their books with examples drawn from many countries. As a result the texts should be of value to English-speaking students of horticulture throughout the world. 
The maner of watering with a Pumpe in a Tubbe.
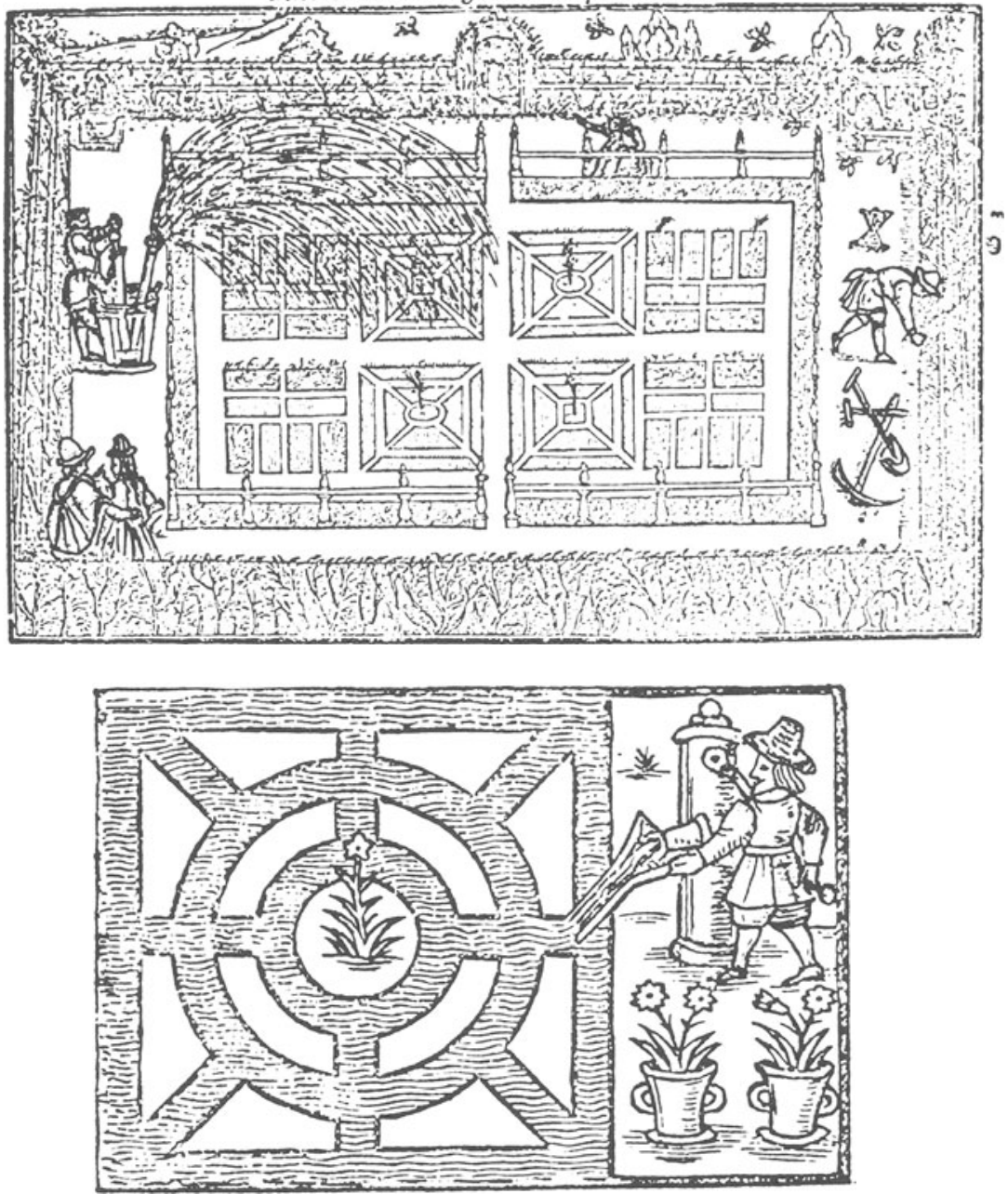

There be fome which ufe to water their beds with great Squirts, made of Tin; in draving up the water, and fecting the Squirt to the breft, that by force fquirted upward, the warer in the breaking may fall as drops of raine on the plants, which lundry times like rquirced on sbe beds,dorh fufficiencly. feed the plants with moifture.

Frontispiece: Elizabethan irrigation, furrow and sprinkle from The Gardeners Labyrinth (Anon.) 1651 


\title{
WATER, SOIL AND THE PLANT
}

\author{
E. J. WINTER \\ Formerly Head of Irrigation Section \\ National Vegetable Research Station \\ Wellesbourne, Warwickshire
}

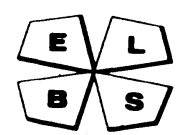

Macmillan Education 
Published in collaboration with the Horticultural Education Association and the Royal Horticultural Society

(C) E. J. Winter 1974

All rights reserved. No part of this publication may be reproduced or transmitted, in any form or by any means, without permission.

First published 1974

Reprinted 1976, 1978

ELBS edition first published 1978

Published by

THE MACMILLAN PRESS LTD

London and Basingstoke

Associated companies in Delhi

Hong Kong Lagos and Singapore

ISBN 978-0-333-12948-7

ISBN 978-1-349-81454-1 ISBN 978-1-349-81452-7 (eBook)

DOI 10.1007/978-1-349-81452-7

Set I.B.M. by

GEORGE OVER LIMITED, LONDON AND RUGBY

The paperback edition of this book is sold subject to the condition that it shall not, by way of trade or otherwise, be lent, re-sold, hired out, or otherwise circulated without the publisher's prior consent in any form of binding or cover other than that in which it is published and without a similar condition including this condition being imposed on the subsequent purchaser. 
All the rivers run into the sea, yet the sea is not full; unto the place whence the rivers come thither they return again.

Ecclesiastes 1:7 


\section{CONTENTS}

Frontispiece

facing page iii

Preface

$\mathrm{xi}$

Introduction $\quad x i i$

1 THE WATER BALANCE 1

Annual rainfall distribution $\quad 1$

Precipitation rate $\quad 8$

Evaporation $\quad 8$

Dew $\quad 8$

Drainage 9

The water balance $\quad 9$

Water need maps $\quad 9$

Measuring the water balance $\quad 11$

2 WATER SUPPLIES FOR HORTICULTURE 23

Sources of water; pumping machinery 24

Abstraction points 24

Cross-stream dams and off-stream pounds $\quad 25$

Artificial lakes and reservoirs $\quad 26$

Wells and boreholes $\quad 26$

Public water supplies $\quad 26$

Land drains $\quad 27$

Underground recharge $\quad 28$

Estuarine barrages $\quad 29$

The sea as a possible source of irrigation water $\quad 29$

Water quality $\quad 30$

Dissolved salts 31

Accumulation of salts in the surface soil 31

Assessing water supplies $\quad 32$

Regulating water abstraction $\quad 34$

3 THE SOIL RESERVOIR $\quad 35$

Soil series $\quad 35$

Soil texture $\quad 35$

Soil horizons $\quad 35$

Drainage $\quad 36$

Pore space $\quad 37$

Soil water potentials $\quad 37$

Matric potential, or suction $\quad 38$ 
viii

Osmotic potential, or suction $\quad 38$

pF $\quad 39$

Soil moisture characteristic $\quad 40$

The lower limit of available water (permanent wilting point) 41

The upper limit of available water (field capacity) 42

Available water capacity $\quad 43$

Apparent specific gravity, or bulk density 48

The influence of structure on available water capacity $\quad 49$

The energy concept of soil water $\quad 49$

Measurement of soil moisture parameters $\quad 50$

4 MOVEMENT OF WATER IN SOIL 61

$\begin{array}{ll}\text { Erosion } & 61\end{array}$

$\begin{array}{ll}\text { Capping } & 62\end{array}$

Water movement in saturated soil $\quad 64$

The wetted front $\quad 65$

The water table $\quad 65$

Impeded drainage $\quad 66$

Water movement in unsaturated soil $\quad 66$

$\begin{array}{ll}\text { Evaporation from soil } & 67\end{array}$

Measurement of soil water movement $\quad 67$

5 THE HYDROLOGICAL STRUCTURE OF VASCULAR PLANTS 71

The water-conducting vessels $\quad 71$

$\begin{array}{ll}\text { Roots } & 71\end{array}$

$\begin{array}{ll}\text { The root system } & 72\end{array}$

$\begin{array}{ll}\text { Stems and foliage } & 73\end{array}$

$\begin{array}{ll}\text { Stomata } & 74\end{array}$

The 'plumbing' system $\quad 74$

General conformation $\quad 74$

Organs which produce mechanical movement $\quad 76$

Measurement of stomatal aperture $\quad 76$

Measurement of stem flow $\quad 78$

6 ENTRY OF WATER INTO THE PLANT 81

Entry of water into the root $\quad 81$

$\begin{array}{ll}\text { Root pressure } & 82\end{array}$

Supply of water to the root $\quad 83$

Growth of roots towards water $\quad 84$

The exploitation of soil available water $\quad 84$

$\begin{array}{ll}\text { Temporary wilting } & 88\end{array}$

Measurement of entry of water into the plant 88

Demonstration and measurement of root pressure $\quad 89$

7 WATER WITHIN THE PLANT 91

$\begin{array}{ll}\text { Transpiration rates } & 91\end{array}$

The water status of plant tissues $\quad 92$ 
Water stress

Results of reduction in plant water potential

Effects on stomata

Gross physiological effects 95

Effects on growth and development 96

Transport 96

Measurement of factors associated with movement of water within the plant

8 MOVEMENT OF WATER OUT OF THE PLANT-SOIL SYSTEM

Boundary layer

Empirical determinations of evaporation

Estimation of evaporation from physical measurements

Potential and actual transpiration

Root constant or crop constant

Incomplete crop cover

106

Soil moisture deficit

Depletion of available water

The significance of transpiration

Measurement of transpiration

Measurement and estimation of soil moisture deficit

9 HORTICULTURAL IMPLICATIONS

Effects of water stress on crop plants

Limited irrigation

Water stress and produce quality

Water stress and growth

Development of water stress

Manipulating available water capacity

Water tables

Soil water conservation

Evaporation reduction in practice

Exploitation of soil reservoir

Glasshouse crop irrigation

Outdoor irrigation

Water, soil and the plant

Appendix The Penman formula 


\section{PREFACE}

This book has been written to fill the needs of students taking either the National Diploma in Horticulture or the new Higher National Diploma in Horticulture which has been introduced recently. It should also prove useful to students in universities taking degree courses in the subject. It draws on information and opinions collected by the author during thirty-five years of collaboration with growers, planters, advisers, scientists and amateur horticulturists in many temperate and tropical countries.

Because of the immense number of people involved it is impracticable to acknowledge them all by name, but I wish to express my grateful thanks to every one; it is a splendid characteristic of the horticultural industry that almost every individual is willing and anxious to share his knowledge and experience for the common good, and especially for the education of newcomers. There are few trade secrets in our industry. Without such generous pooling of knowledge this book could not have been written.

For much the same reasons I have not attempted to produce formal references to original authors for each scientific fact quoted; long lists of references can be daunting to the young student. Instead I have given suggestions for further reading including review papers which contain detailed lists of references for those who require them.

I wish to thank Professor Wright, Director of the National Vegetable Research Station, and my professional colieagues especially Drs Salter, Stanhill, Sale, D. Drew, Cox and Rowse, Messrs Williams, R. Drew, Stone and McKee, Miss Lucy Blackwall and Mrs Joyce Steckel for the use of data and ideas accumulated during our long service together, Miss Jenny Wright who prepared most of the photographs and Miss Angela Rose for her long-suffering secretarial help.

My wife also deserves special mention for good-humouredly accepting the domestic upheaval entailed in writing a book in one's 'spare time'.

Welford on Avon

E. J.W. 


\section{INTRODUCTION}

Everyone knows that plants need water in order to survive, and horticulturists know that to ensure maximum growth they must never allow their plants to suffer from water shortage. It therefore comes as no surprise to the layman to learn that ordinary plants consist of over 90 per cent water; however what may be surprising is that under normal temperate summer conditions a square metre of vegetation transpires about two litres per day or nearly half a gallon per square yard. A mature lettuce plant transpires more than half its own weight of water every sunny day.

The object of this book is to discuss why this happens, how it happens and what use it is to the plant and hence to the horticulturist. The book is not a treatise on irrigation practice; such information is given in the publications cited on page 135 .

Water reaches the soil mainly as rain; some is stored in the soil itself, some drains down through the topsoil into lower layers while if the soil is already saturated some may flow off the surface into drains and streams. Of the water in the soil a portion evaporates from the soil surface and a portion is taken up by the roots of plants and is evaporated, or transpired, from their foliage into the atmosphere. This circulation of water from the atmosphere into the soil and back to the atmosphere comprises the hydrological cycle and is dealt with in chapter 1.

Water supplies for plants are described in chapter 2. These are derived mainly from precipitation, from the water table or from upward or lateral movement of water within the soil. Supplementary water for irrigation may be obtained from streams, lakes, ground-water wells or deep boreholes. The quality of this water sometimes gives cause for concern as it may be more or less saline or contain harmful pollutants such as surfactants (detergents) or toxic materials derived from industrial wastes.

Chapter 3 describes the nature of soil, which consists of various sized particles of inorganic and organic matter having irregular shapes and therefore not fitting closely together. The voids thus left may be filled with air or water and constitute the all-important soil reservoir. The capacity of this reservoir is greatly influenced by the soil texture, that is, its particle size spectrum.

It follows from what has been said of the entry of water into the soil and its removal by plants, drainage and evaporation that the soil water is not static; it is in a continuous state of movement downwards or sideways 
in mass flow or upwards by capillary action. The rates of these movements are largely controlled by the soil texture and by local differences in soil moisture content which result from surface evaporation, precipitation and uptake into roots. The dynamic state of the soil water is discussed in chapter 4.

Chapter 5 gives structural details of those parts of vascular plants involved in the transfer of water from the soil into the atmosphere, namely the root system which has tissues capable of absorbing liquid water and transferring it into the xylem vessels, the xylem tube system itself, and the cells in the foliage which receive the water from the upper ends of the vessels and evaporate it from their surfaces into the intercellular spaces whence it moves back into the atmosphere mainly through the stomata. Entry of water into the plant and its relationship with the entry of solutes and the functioning of the root system as a whole in exploiting soil available water are described in chapter 6 .

Chapter 7 discusses water within the plant, the development of internal water stress and its effect on growth, and the mechanism by which water is raised to the tops of the tallest trees. Internal water stress affects the plant in many ways and can have disastrous effects on growth and yield. Transpiration, the movement of water out of the plant into the atmosphere, is mainly a passive process whose maximum rate depends upon the quantity of energy available from sunlight and from advective sources and whose actual rate is governed by factors such as resistance to water uptake from the soil, resistance to movement within the plant, and the temperature, humidity and motion of the air surrounding the foliage. Chapter 8 is concerned with the loss of water from the foliage and with methods for estimating transpiration from meteorological observations and hence the desirable amounts and timing of supplementary watering.

The bad effects of water stress on crop growth and production can be countered by measures for improving the structure and texture of the soil, for conserving water in the soil reservoir, manipulating the water table and augmenting natural rainfall by judicious irrigation; the practical application of such measures is discussed in the final chapter 9. A section of this chapter deals with the special problems of meeting the water needs of plants grown under protection such as that provided by glasshouses, often in pots or other containers. Here there is usually no contribution from rain, evaporative conditions may be severe and the soil reservoir comparatively small; the general principles are the same as those apertaining to open fields but the methods of applying them are different.

In some climates irrigation enables crops to be grown in otherwise unproductive places or seasons of the year; in less rigorous climates supplementary watering can increase yield and quality out of all proportion to its cost. However in each of these circumstances haphazard and indiscriminate irrigation can be expensive, unproductive and even harmful. It is the purpose of this book to expound the principles 
underlying the profitable use of the soil reservoir in exploiting natura! water resources and supplementing these with irrigation only when this is economically worthwhile.

Throughout the book descriptions have been given of methods and instruments for measuring factors associated with the movement of water in soil and plants. Many of the devices can be made from comparatively simple components and the exercise will help the student to appreciate the principles involved. Most of these instruments were originally devised for research and if in difficulty the student should refer to the publication cited. As indicated in the text, a few have been adapted for use in horticulture but the busy grower is understandably reluctant to adopt devices which need frequent attention and for this reason good watering principles which depend on instrumentation have not been generally applied in practice. The student might well consider ways of simplifying appropriate research devices while still retaining sufficient accuracy for application in practical horticulture. 